\title{
Tech Waste: Environmental Impact and Management
}

\author{
Sangeeta Kumari \\ School of Information Technology, \\ MATS University, \\ Raipur, Chhattisgarh, India-493447
}

\author{
Bincy K Baby \\ School of Information Technology, \\ MATS University, \\ Raipur, Chhattisgarh, India-493447
}

\begin{abstract}
Over the recent years, the global market of electrical and electronic equipment (EEE) has grown rapidly, while the products lifespan has become increasingly shorter. The rapid growth of the electronic and IT industry, current user's culture, increasing rates of usage of techno products have led to disastrous environmental consequences. Most of these technologies are ending up in backlash and recycling centres, posing a new environmental challenge in this 21 st century. The presence of hazardous and toxic substances in electronic goods has made tech waste a matter of fear and if not properly managed, it can have unfavourable effects on environment. It has been proven that some of the waste contain many cancer-causing agents. This paper provides a review of the tech waste problems and the need for its appropriate management.
\end{abstract}

Keywords: Tech Waste; Environmental Impact; Management; Recycling

\section{INTRODUCTION}

Tech Waste consists of waste generated from used techno devices, electronic appliances which are not fit for their original use and are put-up for recovery, recycling. These wastes consist of various electrical and electronic devices like PCs, mobile phones, including household appliances like refrigerators, air conditioners, television etc. Tech waste contains of thousand different materials many of which are toxic and potentially hazardous to atmosphere and human health ${ }^{[5]}$.

The rapid development of information technologies are being considered as the turning point of human civilization in the afterwards of 20th century and 21st century. The Information Technology has been the strength of the universal economy since 1990s. Frequently increasing production of computer hardware has become major challenges of proper disposal of waste (techno-waste) produced by industries. Recent study focuses on the effect of consumption, dumping and recycling of the electronic waste on the natural atmosphere [8].

During the last decade electronic industry is the largest and fastest growing manufacturing industry. The outcome of its consumer oriented growth combined with fastest product disuse and technological advances are a new environmental objections- the growing danger of tech waste. [3] Information Technology is a developing problem as well as venture opportunity of increasing significance, given the volumes of tech waste being produced and the content of both toxic and valuable substances present in them. In tech waste over $60 \%$ is iron, copper, aluminum, gold and other metals, while plastic is about $30 \%$ and the hazardous pollutants consist only about $2.70 \%$. [7]

\section{CURRENT SCENARIO}

\subsection{Global Scenario}

As per the global e-waste management, Switzerland is the first country to come up with the organized e-waste management system in world. The base of tech waste management system in Switzerland and other developed countries is Extended Producer Responsibility (EPR) and Advance Recycling Fee (ARF). In countries like USA, UK, France \& Germany 1.5 to 3 million tons of e-waste are generated annually and are among the largest generators of e-waste. But in these countries also standardized e-waste management processes takes place. Organized and proper e-waste management, from potential sourcing and collection right up to ejection and disposal of material, has ensured that this huge heap of trash turns into a profitable business opportunity. India, China and few African countries have become dumping sites to the developed countries. Due to very drastic environmental standards, the expense of collection, preprocessing, recycling and disposal are very high. There are many countries that started the 'take back' system for their electronic product and have made laws on e-waste management. The US Environment Protection Agency has started National Electronics action Plan in USA to address the various issues related to e-waste. The European Union (EU) has put forward two frameworks for environmental protection from e-waste i.e., WEEE (Waste Electrical and Electronic Equipment) directives and RoHS (Restriction of use of Certain Hazardous Substances) which are also implemented by other countries. As per the EU directives (2003), it is compulsory for all 27 countries of European Union to recycle their waste. [5] In 2014 around $41.8 \mathrm{Mt}$ tech waste generations was there in global quantity. [15] A UN report estimates that 30-50 million ton e-waste is generated yearly worldwide. Nearly $50-80 \%$ of e-waste are exported by US for recycling as export is legal in US. The export is due to cheaper labor in developing countries. The recycling and disposal of e-waste in China, India and Pakistan is highly polluted due to the release of toxic chemicals. The lack of responsibility on the part of government for the sustainable disposal of e-wastes have given a way for the development of unorganized sectors for the informal growth of e-waste. [17]

\subsection{Indian Scenario}

According to Aug 2014 report by Industrial body ASSOCHAM, large usage of gadgets, telecom, IT and appliances is collectively creating nearly 13 lakh tons of ewaste yearly in India. The insight in report is that DelhiNCR, Mumbai and the IT capital of India, Bangalore collectively produce over 2 lakh tons of e-waste annually. Another January 2015 report from Merchandise and Research has predicted that the Indian e-waste market will grow at the rate of 26.22\% CAGR (Compound Annual Growth Rate) during 2014-2019. As per the report, so much technological 
waste being generated in the Country, a big portion is handled by the unofficial or unorganized sector using improper processes, which leads to pollution that affect the environment and develop many health hazards [16].

\section{ENVIRONMENTAL IMPACT}

Roughly each year 40 million metric tons of electronic waste (e-waste) is produced globally, about 13 percent of that weight is recycled in developing countries. According to United Nations Environment Programme (UNEP) 9 million tons of this waste such as discarded televisions, mobile phones, computers, and other electronics are produced by the European Union. And UNEP notes that this estimate is too low. About $50 \%$ to $80 \%$ of this e-waste is handled by informal recycling markets in China, Vietnam, and Philippines, often shredding, burning and separating the parts of products in backyards. Emissions from the recycling practices are damaging human health and environment.

Developing countries with fast growing economies handle e-waste from developed countries and their own consumer's. Currently it is estimated that 70 percent of ewaste handled in India is from other nations, but between 2007 and 2020, homely television e-waste will double, computer e-waste will increase 5 times, and cell phones 18 times as per UNEP estimates. The health risks are increased by the recycling practices done by informal sectors. For example, exposure to toxic metals, such as lead, results mainly from burning in open air that is used to retrieve components such as gold.

Burning e-waste release inflammation, it creates fine particulate matter, which cause pulmonary and cardiovascular disease. So several studies in Guiyu, a southeastern City in China, offer insight that the health implications is difficult to isolate due to the informal working conditions, poverty and poor sanitation. Guiyu is the biggest e-waste recycling site in the world, and the city's residents face substantial digestive, neurological, respiratory, and bone problems. For example, $80 \%$ children in Guiyu's face respiratory ailments, are at a risk of lead poisoning. E-waste is now the most important global environmental and health issue. Some policy responses have been arisen from European Union, which states source as responsible for e-waste. With this approach, manufacturers are required to eliminate dangerous toxins from production. [11]

Electronic equipment's are made up of a number of components. Some components contains toxic substances which have an adverse impact on the health and environment if not handled properly. These hazards arise due to the improper recycling and disposal processes used. [3]

\subsection{Environmental Impact by Different Types of Electronic Components [12]}

\section{Cathode ray tubes}

Cathode ray tube is used in TVs, Computer monitors, ATM, Video cameras, and more. Process used for dismantling and disposal are, breaking and removal of yoke, then dumping. Hazard which affect the atmosphere is such as lead, Barium and other heavy metals extract into the ground water and it releases the toxic phosphor.

\section{Printed circuit board}

It is a thin plate on which chips and other electronic components are placed. Process used for dismantling and disposal are, computer chips are removed by Desoldering process. Chips are removed then open burning and acid baths to remove final metals. Hazards which effect the atmosphere is air emissions and the discharge of glass, dust tin, lead, beryllium cadmium and mercury into rivers.

\section{Chips and gold plated instrument}

Process used for dismantling and disposal of this component are, chemical stripping using nitric and hydrochloric acid and burning of chips. Environmental hazards are Hydrocarbons, heavy metals, brominated substances discharged into rivers directly, which is acidifying fish and flora. Tin and lead contamination of surface and groundwater. Hydrocarbons, heavy metals and brominated dioxins are emitted into air.

4. Plastics

Plastics which are used in printers, keyboards, monitors etc. The process used for reuse of the devices are shredding and melting at low temp. Environmental hazards are emission of heavy metals, hydrocarbons and brominated dioxin.

5. Computer wires

Wires which are used in the computer. To reuse the components process used are burning in open air and stripping for copper removal. The environmental hazards are hydrocarbon ashes which released into soil, air and water.

\subsection{Effect on Human Being [17]}

- The waste element Lead effects the central and peripheral blood system, nervous system, reproduction system and kidney. The source of this waste is Glass panel, Gasket in computer monitors, solder in PCB and other component.

- The waste element Cadmium effects the kidney. The source of this waste is SMD chip registers, semiconductor chips and infra-red detectors.

- The waste element Mercury effects the brain, kidney, and foetus. The source of this waste is electrical and electronic equipment thermostats, relays, sensors, switches, medical equipment, lamps, mobile phone, batteries, flat panel display.

- The waste element Barium causes brain swelling, muscle weakness, damage to heart, liver and spleen. The source of this waste is component used in computer's front panel of a CRT.

- The waste element Beryllium causes lung cancer, skin diseases. The source of this waste is motherboard, finger clips.

- The waste element Toners causes the respiratory treat irritation. The source of this waste is plastic printer cartridge.

- The waste element Hexavalent chromium causes damage to DNA. The source of this waste is untreated steel plant. 


\section{TECH WASTE MANAGEMENT}

\subsection{Tech Waste Management Strategies}

The best way to handle e-waste is to decrease the volume of ewaste generated. Designers should take care that the product is built for re-use, repair or upgradeability. Stress should be laid on the use of less toxic, easily recoverable and recyclable materials in these technologies such that it can be reused again. Recycling and reuse of materials are the best way of ewaste management. Magnitude of e-waste can be reduced by recovery of metal, plastic, glass and other materials. By doing so energy can be conserved and the environment can be kept free from toxic materials that would have been released otherwise.

Now it is the high time the manufactures, consumers, regulators, state governments, municipal authorities, and policy makers take up the matter sincerely so that the different critical elements addressed in proper manner. It is the time to have an "e-waste policy" and national regulatory framework for the proper management of e-waste. An e-waste policy can be best made by those who understand the in-depth issues caused by e-waste. So it is best for industry to have policy formation with user involvement. By improving the performance of collection and recycling systems the sustainability of e-waste management can be achieved. ${ }^{[7]}$

\subsection{Status of Tech Waste Management in India}

Although of a wide range of environment legislation in India there is no specific laws for the guidelines for e-waste or tech waste. As per the Hazardous Waste Rules (1989), unless it is proved to have higher concentration of certain substance ewaste is not treated as hazardous.

Following action /steps has been taken by government to raise the awareness about environmentally sound management of techno waste (CII, 2006):

- Several workshops of e-waste management was organized by the Central Pollution Control Board $(\mathrm{CPCB})$ in association with Toxics Link, CII etc.

- $\mathrm{CPCB}$ has initiated the action for rapid estimation of the E-waste generated in major cities of the country.

- A National Working Group has been formed for developing a scheme for E-Waste Management.

- "Environmental Management for Information Technology Industry in India"- A comprehensive technical guide, has been published and circulated widely by the Department of Information Technology (DIT), Ministry of Communication and Information Technology.

- Demonstration projects have also been set up at the Indian Telephone Industries by the DIT for recovery of copper from Printed Circuit Boards.

Despite awareness and readiness for implementing improvements is increasing speedily, the major hurdle to manage the e-waste safely and effectively continues. These include -

- The lack of reliable data that stand as a challenge to policy makers who wish to design an e-waste management strategy and to an industry wishing to make analytical investment decisions.

- Due to absence of a useful take back scheme for consumers only a portion of the e-waste (estimated $10 \%$ ) finds its way to recyclers.
- The lack of a safe e-waste recycling framework in the formal sector and thus dependence on the capacities of the informal sector pose severe risks to the environmental and human health.

- The existing e-waste recycling systems are purely business-motivated that have come about without any government intercession. Any development in these ewaste sectors will have to be built on the current set-up as the waste collection and pre-processing can be handled efficiently by the informal sector, at the same time offer numerous job opportunities. ${ }^{[9]}$

\subsection{Approaches for E-Waste Management}

"Reduce, Reuse, Recycle" should to be adopted for tech waste management. Reduce the generation of e-waste through smart procedure and good maintenance. Reuse still functioning electronic devices by giving or selling it to someone who can still use it. Recycle only those components that cannot be repaired. Use only authorized recyclers for disposing the ewaste products. ${ }^{[10]}$

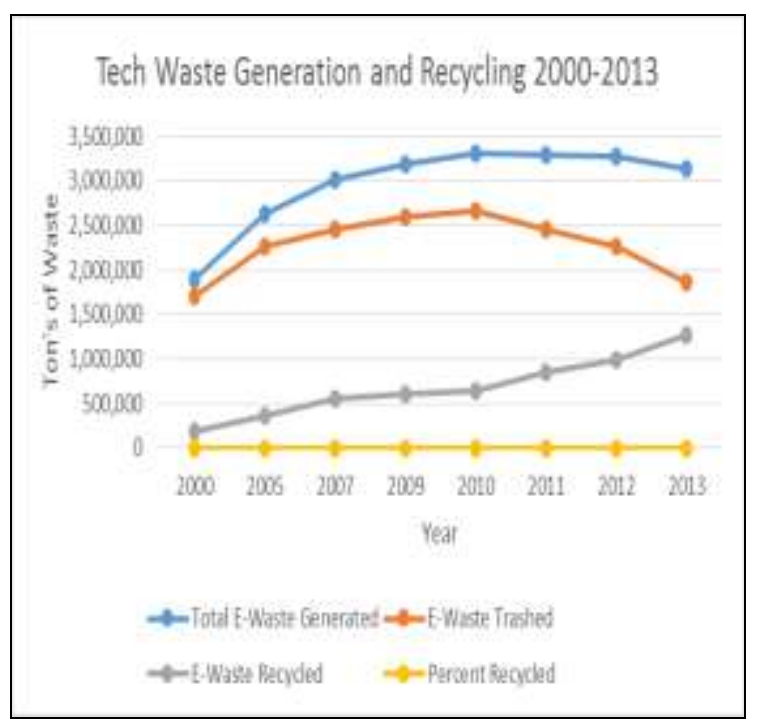

Figure.1 Tech Waste Generation and Recycling 2000-2013 [13]

\subsection{Methods for E-Waste Management [16]}

\section{Land filling}

Most commonly used method for disposal of e-waste is land filling. In this method flat surfaces are trenched. Soil is removed from the trenches and waste materials is buried into it, which is covered by thick layer of soil. The degradation process in landfills are very complicated and take a wide time to run. The various hazards of land filling are leaking landfills, leach ate contaminating soil and groundwater, Chemical reactions, vaporization, uncontrolled fires. Thus land filling is not environmentally good treatment for substances, which are volatile and non-biologically degradable $(\mathrm{Cd}, \mathrm{Hg}$, $\mathrm{CFC}$ ), persistent (polychlorinated biphenyls [PCB]) with unknown behavior in a landfill site (brominates flame retardants).

\section{Incineration}

Incineration is a complete and controlled combustion process, in which specially designed incinerators are 
used in which the waste materials are burned at a high temperature $\left(900-1000^{\circ} \mathrm{C}\right)$. Advantage of this method is that volume of waste will be reduced and the utilization of the energy content of inflammable materials. Disadvantage is that some escaping substances of flue gas and large amount of residues from gas cleaning and combustion process is emitted into air. Cadmium and mercury are emitted yearly from e-waste incineration plant. Heavy metals are not emitted directly into the atmosphere and it is transferred into slag and exhaust gas residues which can reenter the atmosphere on disposal. So incineration will increase these emissions if no reduction are taken like removal of heavy metals. Incineration Hazards are as follows: Dioxin formation, heavy metal contamination, contamination slag, fly ash, and flue gas, health and safety hazards.

\section{Recycling of e-waste}

The three types of recycling options for managing plastics from end-of-life of electronics they are Mechanical recycling, chemical recycling and thermal recycling. Recycling process involves dismantling, that is, removal of different parts of electronic devices which contain many dangerous substances like $\mathrm{PCB}, \mathrm{Hg}$, separation of plastics, CRT, ferrous segregation and nonferrous metals and printed circuit board. Many precious metals like lead, gold, copper are removed by use of strong acids which affect the atmosphere and human health also. The value of recycling process of any electronic devices is much higher if technologies are used. The persons who recycle the e-waste works in poorly- ventilated enclosed areas without any mask and technical expertise results in exposure to dangerous and slow poisonous chemicals. Devices which can be are recycled are Monitors and CRT, keyboards, laptops, CPUs, chips, mobile phones, compact disks, fax machines, hard drives, floppy disks, telephone boards, modems, connecting wires and cables. Effects due to ewaste recycling are: threat to human health and environment, Lead causes damage to the kidneys, central and peripheral nerve system and blood system in humans, Mercury impacts brain development and functioning.

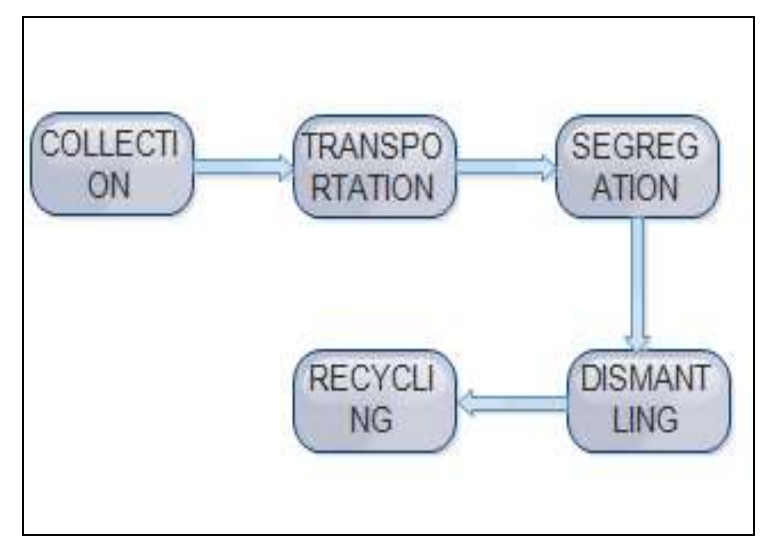

Figure.2 Process of Tech waste Recycling ${ }^{[18]}$

\section{Reuse}

It is direct second-hand use or use after slight modifications to the original device. It is used for electronic devices such as computers, cell phones, etc. Inkjet cartridge is also used after refilling. This method also reduces e-waste generation.

\section{CONCLUSION}

Tech Waste is a growing factor in the world because of the fast development of the electronic and IT industry. The toxic materials present in the techno products is harmful for health and environment. The best way is to have a proper management of the tech waste so that it will turn to profitable product and also a business opportunity for entrepreneur. We should reduce the usage of technology in our day to day life. We can also promote awareness among people about the proper tech waste management. Manufacturers, designers have the responsibility to ensure that the substances used in electronic products can be recycled and reused later such that it does not affect the atmosphere. Improper management of Tech waste is disastrous for human's health, it leads to various types of diseases that are not cured because they are new for doctors. There are some places in India where recycling of Technology products take place. The recycling of disposed techno waste occurs in few places of foreign country like Switzerland, Europe etc.

\section{REFERENCES}

[1] G. Gaidajis, K. Angelakoglou and D. Aktsoglou, "Ewaste: Environmental Problems and Current Management", Journal of Engineering Science and Technology Review 3 (1) (2010) 193-199.

[2] M. Khurrum S. Bhutta, Adnan Omar, and Xiaozhe Yang, "Electronic Waste: A Growing Concern in Today's Environment", Economics Research International Volume 2011 (2011), Article ID 474230,Website:http://www.hindawi.com/journals/ec ri/2011/474230/.

[3] Dr. C.Subburaman, "E-Waste Hazardous: Impacts on Environment and Human Health", International Journal of Pharmaceutical \& Biological Archives 2012; 3(2):363-367, ISSN 0976-3333.

[4] Ms. Sukeshini Jadhav, "Electronic Waste: A Growing Concern in today's environment sustainability", International Journal of Social Science and Interdisciplinary research, Vol.2 (2), February (2013), ISSN 22773630.

[5] Shagun, Ashwani Kush, and Anupam Arora, "Proposed Solution of e-Waste Management", International Journal of Future Computer and Communication, Vol. 2, No. 5, October 2013.

[6] Dr. B. J. Mohite, "Issues and Strategies in Managing EWaste in India", Indian Journal of Research in Management, Business and Social Sciences (IJRMBSS), I ISSN No. : 2319-6998 I Vol. 1 I Issue 1 I Mar. 2013.

[7] Vijay N.Bhoi and Trupti Shah, "E-Waste: A New Environmental Challenge", International Journal of Advanced Research in Computer Science and Software Engineering, Volume 4, Issue 2, February 2014, ISSN 2277 128X

[8] Kurian Joseph, "Electronic Waste Management in IndiaIssues and Strategies", Proceedings Sardinia 2007, Eleventh International Waste Management and Landfill Symposium S. Margherita di Pula, Cagliari, Italy; 1 - 5 October 2007.

[9] Binay Kumar, "E-Waste - Environment and Human Health Hazards and Management", IRSEE / Prof. (Network Management) / NAIR, Vadodara. 
[10] The Human and Environmental Effects of E-Waste, Website:

http://www.prb.org/Publications/Articles/2013/ewaste.aspx.

[11] Electronic Waste, Website: https://en.wikipedia.org/wiki/Electronic_waste.

[12] E-Waste in Landfills, Website: http://www.electronicstakeback.com/designed-for-thedump/e-waste-in-landfills/.

[13] The Global E-Waste Monitor 2014 Quantities, flows and resources, Website: http://i.unu.edu/media/unu.edu/news/52624/UNU1stGlobal-E-Waste-Monitor-2014-small.pdf.

[14] Nitin Sinha, "E-waste in India: The Current Scenario 2014 Update", Website: http://attero.in/blogs/e-waste-inindia-the-current-scenario-2014-update/.
[15] Jayapradha Annamalai, "Occupational health hazards related to informal recycling of E-waste in India: An overview", Indian Journal of Occupational; and Environmental Medicine, Year: 2015, Volume: 19, Issue: 1, Page: 61-65.

[16] Dr. Devendra S Verma and Shekhar Agrawal, "E-waste management in India: Problems and Legislations", International Journal of Science, Engineering and Technology Research (IJSETR), Volume 3, Issue 7, July 2014.

[17] E-Waste recycling process in India followed by Exigo, Website: waste_recycling_process.html. http://exigorecycling.com/e-

[18] CII (2006). "E-waste management", Green Business Opportunities, Vol.12, Issue 1, Confederation of Indian Industry, Delhi 